\title{
Science Process Skills of Eigth-Grade Students at SMPN 2 Masbagik
}

\author{
Baiq Fatmawati \\ Biology Education Program \\ Hamzanwadi University \\ West Nusa Tenggara, Indonesia \\ f_baiq@yahoo.com
}

\begin{abstract}
This study was conducted to know the science process skills of eight-grade students at SMP N 2 Masbagik. A total of 160 eight-grade students at SMPN 2 Masbagik, East Lombok, Indonesia, were used as research population and 30 of them were selected as sample by using cluster random sampling. The science process skills of the sample were measure after they taught on the subject of photosynthesis. The result of this study shows that the students' science process skill of the eight-grade student at SMP N 2 Masbagik was low category. It is indicated that the student skill must be increased and appropriate learning methods can be used as the way to solve the low students' science process skill.
\end{abstract}

\section{Keywords: science process skill, junior high school student}

\section{INTRODUCTION}

Science is a natural learning concept that is very closely related to human life. Science studies facts in the universe and plays an important role in education and technological development.

In Indonesia, science is taught in junior high schools as integrated science learning. Science learning process is applicable and oriented on development of learning, thinking, curiosity, care and responsibility towards social and natural environment. Science is taught at school to prepare students who have scientific literacy skills, high-order thinking skills, good values and good attitudes. Student who has these abilities become creative, innovative, communicative and collaborative [1,2].

References [3] state that the main purpose of science education is to teach students about integrating skills, knowledge, and attitudes in understanding scientific concepts. Therefore, teachers must focus on teaching science skills such as facts, concepts and theories in encouraging students to conduct scientific investigations.

As a process, science plays a role in discovery and development of knowledge. Students must have ability to do things that use scientific processes and principles. Learning to know and learning to do must be achieved in teaching and learning activities [4].

Science has a process of building knowledge. In this process, junior high school students have a basic idea of science. They explore their knowledge and learn from their experiences in and outside the classroom. Science process skill is one of appropriate methods that used by the students. This skill is used to investigate their surrounding environment and to develop science concepts. Science process skills help students become active in the learning process of the scientific method [5]. Therefore, the teacher must have a good understanding of this skill [6].

Science process skills are identical to observations or experiments to see students' abilities in observing carefully, grouping, predictions, questions, hypothesizing, and how to communicate the results of their observations. Some researches on students' science process skills have been conducted. Reference [7] observes science process skills of elementary school students with situation models or real experiments related to six model assignment tests. Meanwhile, the development of science process skills and problem solving abilities based on outdoor learning in junior high schools has been carried out. In addition, researcher measured science process skills of junior high school students with experiments on the concept of buoyancy [9].

Based on these studies, the researchers conducted research on science process skills by giving essay questions; they did not do it experimentally. For example, a research has been carried out by making tests in the form of 7 scenarios and 9 multiple-choice questions equipped reasons for primary school teachers in the Aegean region in Turkey [10].

Based on the important of science process skills explained above, this research was conducted to measure the students' science process skills of eight-grade students at SMP N 2 Masbagik, East Lombok, Indonesia.

\section{METHOD}

Design of this study was a pretest-posttest control group design. This research was conducted at SMPN 2 Masbagik, East Lombok, Indonesia, in the academic year 2014/2015. Population of this study was 160 students of eight-grade students distributed into 5 classes, namely VIII A, VIII B, VIII C, VIII D, and VIII E. Research samples were 30 students of VIII E and were selected by cluster random sampling technique. Students were taught using lecture method on the subject of photosynthesis. After the learning, the science process skills of students were measured using post-tests. Data collection techniques using essay tests and the data were collected on April 27 to May 172015. Assessment instrument was 6 essay tests consists of science process skill indicators i.e. (1) Observing (observation), (2) grouping (classification), (3) interpreting (inference), (4) predicting (predicting), (5) asking questions, and (6) hypothesizing. Proposed science process skill indicators are guided by reference [12]. 


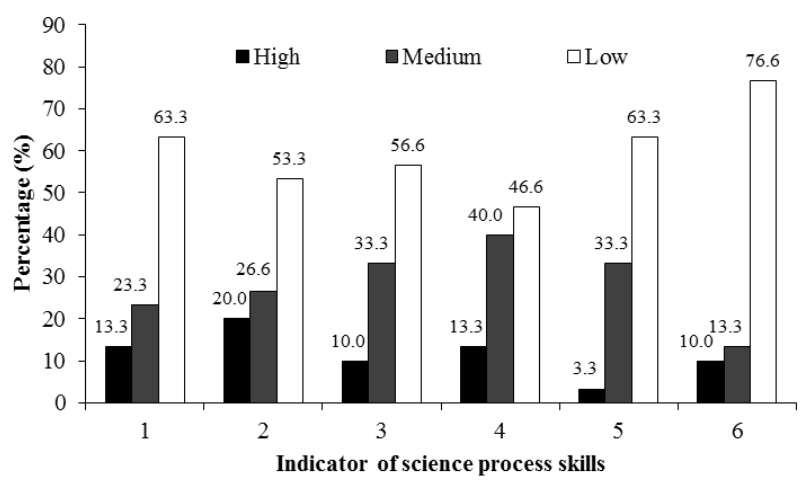

Fig. 1. Percentage of students' science process skills, science process skills indicators including (1) observation, (2) grouping, (3) interpreting, (4) asking questions, (5) hypotheses, (6) communicating.

\section{RESULTS AND DISCUSSION}

Science process skills need to be developed as learning experiences because they involve cognitive abilities, manual and social skills [13]. In addition, students are more concentrated and focused on the application of concepts; they realize and appreciate the learning process, so that the concepts obtained are more meaningful. Through introduction of science process skills, students are expected to grow their basic science skills, such as the ability to observe, infer, measure, predict, communicate, and classify [14]. Science process skills of students of VIII E SMP N 2 Masbagik are shown in fig. 1.

Based on the Fig. 1, in general, students' science process skills for each indicator are in low category. It shows that students were not familiar with science process skills. A similar result occurred in previous studies, the science process skills of Lampung junior high school students were classified as low category [15]. This phenomenon is caused by of curiosity of the students towards the subject presented and lack of innovation in learning process. As a result, students were less interested in participating in the learning. This phenomenon should be an important concern for teachers to intensively introduce science process skills to students. Introduction of science process skills to students must be in accordance with the characteristics of subject. The introduction of science process skills can be combined with learning methods, such as observing real events or objects and experiments. These actions can improve students' understanding of science process skills. By understanding science process skills, science becomes more interesting, so that it can enhance students' positive attitudes towards science [3]. During the learning process at school, assignments in textbooks, worksheets, material summaries can increase student activity [8]

Science process skills are needed in gaining knowledge and disseminating the acquired knowledge, so as to increase the optimal use of mental and psychomotor skills [16]. Science is used to understand environment systematically. Therefore, science process skills must be utilized by teacher in conveying facts clearly. The presence of scientific activities in learning process can improve students' science process skills. Scientific activities trigger the emergence of scientific attitudes of students and train students' process skills, so students are able to actively participate in investigations [17].

Therefore, the teacher is responsible for developing students' process skills, as a supporter in developing mastery of science concepts, and can provide good learning outcomes [18].

Teaching and learning of science process skills serves as the basis of scientific method and is a valuable opportunity to learn nature of science. Effective science learning depends on methods and techniques used by the teacher during teaching process [19].

\section{CONCLUSION}

Science process skill has the characteristics of basic abilities in learning science such as observing, classifying, measuring, predicting, communicating, and concluding. Science process skill needs to be introduced to students since they are in elementary school. In the process of introducing science process skill, teachers must be able to combine learning with various methods such as observation and experimentation. Through these two methods, students can explore nature, so that the concept of science is clearly understood. Assessment of science process skills can use essay tests.

\section{ACKNOWLEDGMENT}

Thanks to Nurhidayati who helped the author during the data collection process and to head of SMPN 2 Masbagik who had given permission the author to conduct this research.

\section{REFERENCES}

[1] NSTA, National science education standars. Washington: National Academy Press, 2006.

[2] Liliasari, "Membangun masyarakat melek sains berkarakter bangsa melalui pembelajaran". [Presented at the 2011 National Science Education Seminar "Building Literacy Communities Cultured Science with National Character through Learning Science". Semarang, April, 16th 2011].

[3] A.H. Zeidan and M.R Jayosi, "Science process skills and attitudes toward science among palestinian secondary school students," World Journal of Education, vol. 5, 2015, pp. 13-24.

[4] UNESCO, Working paper series on mobile learning: turning on mobile learning in latin america. Paris. UNESCO, 2012.

[5] Z. Fulya, Z. Yusuf, and S. Fatih, "Examining secondary school student scientific process skill in terms of some variabel." Procedia Social and Behavioral Sciences, vol. 106, 2013, pp. 1181-1189.

[6] N. Gultepe, "High school science teachers' views on science process skills". International Journal of Environmental \& Science Education, vol. 11, 2016, pp. 779-800.

[7] M. Hodosyova, J. Útla, M. Vanyová, P. Vnuková, and V. Lapitková, "The development of science process skills in physics," Education Procedia-Social and Behavioral Sciences. 186, 2015, pp. 982-989.

[8] S. Wahyuni, Indrawati, Sudarti, and W. Suana, "Developing science process skills and problem solving abilities based on outdoor learning in junior high school." Jurnal Pendidikan IPA Indonesia, vol. 6, 2017, pp. 165-169.

[9] E. S. Safaah, M. Muslim, and W. Liliawati, "Teaching science process skills by using the 5-Stage learning cycle in junior high school." International Conference on Mathematics and Science Education (ICMScE), IOP Conf. Series: Journal of Physics: Conf. Series 895, 2017. 
[10] B. Aydogdu, M. Erkol, and N. Erten, "The investigation of science process skills of elementary school teachers in terms of some variables: Perspectives from Turkey." Asia-Pacific Forum on Science Learning and Teaching, 15, issues 1, 2014, pp.1-28.

[11] W.R. Borg, M.D. Gall., and J.P. Gall, Educational research an introduction, 7th ed., New York: Longman Inc., 2003.

[12] Sitiativa, Desain belajar mengajar kreatif berbasis sains, Yogyakarta: Diva Press, 2013.

[13] B. Fatmawati, "Menilai keterampilan proses sains siswa melalui metode pembelajaran pengamatan langsung". Presented at the national seminar," National Seminar X Biology Education FKIP UNS Biology, Science, Environment, and Learning" FKIP UNS-Surakarta, vol. 10, 2013, pp 1-9.

[14] R.A.A. Rauf, M.S. Rasul, A.N. Mansor, Z .Othman, and N. Lyndon. "Inculcation of science process skills in a science classroom. Asian Social Science, vol. 9, 2013, pp. 47-57.
[15] Sunyono, "Science process skills characteristics of junior high school students in lampung." European Scientific Journal, vol. 14, 2018, pp. $32-45$.

[16] P. Turiman, O. Jizah, M.D. Adzliana, and O. Kamisah, "Fostering the 21 century skills through scientific literacy and science process skills," Procedia - Social and Behavioral Sciences, vol. 59, 2012, pp. $110-116$.

[17] S. Karamustafaoglu, "Improving the science process skills ability of prospective science teachers using i diagrams," Eurasian Journal of Physics and Chemistry Education, vol. 3, 2011, pp. 26-38.

[18] M. Rizal, "Pengaruh pembelajaran inkuiri terbimbing dengan multi representasi terhadap keterampilan proses sains dan penguasaan konsep IPA Siswa SMP," Jurnal Pendidikan Sains, vol. 2, 2014, pp. 159-165.

[19] R.S. Das, Science teaching in school, New Delhi: Sterling Publishers, 1985 . 